УДК: 378. 147: 314/316: [- 027,543:159.923.2]-:057.87:373.55

DOI: $10.35619 /$ iiu.v2i11.224

Онищенко Неля аспірантка кафедри методики навчання суспільних дисциплін і гендерної освіти Національного педагогічного університету імені М.П. Драгоманова, м. Київ, Україна

ORCID: 0000-0002-6135-6196

e-mail: nelionyshchenko@gmail.com

\title{
МЕТОДОЛОГІЧНІ ЗАСАДИ ПІДГОТОВКИ МАЙБУТНІХ УЧИТЕЛІВ ПРЕДМЕТІВ СУСПІЛЬСТВОЗНАВЧОЇ ГАЛУЗІ ДО ФОРМУВАННЯ НАЦІОНАЛЬНОЇ ІДЕНТИЧНОСТІ УЧНІВ ЛІЦЕЇВ
}

Анотація. У статті визначено методологічні засади підготовки майбутніх учителів предметів суспільствознавчої галузі до формування національної ідентичності учнів ліцеїв. Досліджено виклики (маргінальна або розмита національна ідентичність молоді, високі міграційні настрої і бажання самореалізуватися, відірваність від національної культури, ціннісна невизначеність і зорієнтованість на псевдоцінності, підміна смисложиттєвих цінностей тимчасовими цілями, бажання уникнути служби в армії, громадянська пасивність) і проблеми щодо підготовки майбутніх учителів предметів суспільствознавчої галузі до формування національної ідентичності особистості. Перепонами до формування національної ідентичності у молоді $\epsilon$ політика невизнання, негативні стереотипи, упередження, інформаційна війна. У роботі використано такі методи: теоретичні - аналіз, систематизація та узагальнення методологічних засад та наукових принципів 3 проблеми підготовки майбутніх учителів суспільствознавчої галузі до формування національної ідентичності учнів ліцеїв. Виявлено основні методологічні підходи (особистісно орієнтований, аксіологічний, компетентнісний) та принципи (моделювання професійної діяльності у навчально-виховному процесі закладу вищої освіти, інтегративності, єдності соціалізації і професіоналізації, професійної мобільності, природовідповідності, гуманізму, ментальності, суб'єкт-суб'єктної взаємодії), які протистоять директивній педагогіці. У статті окреслено ціннісно-смислове поле національної ідентичності через національну мову, національну ідею, національні інтереси, національну згоду, національну культуру, історію та традиції нації, а також схарактеризовано психологічні механізми формування національної ідентичності (національна свідомість і самосвідомість, національне самопізнання, національне самоствердження). Проаналізовано нормативну базу з проблеми дослідження. Усі розглянуті методологічні підходи щодо проблеми підготовки майбутніх учителів предметів суспільствознавчої галузі до формування національної ідентичності учнів ліцеїв засвідчують про взаємозв'язок та взаємозалежність наукових підходів та принципів.

Ключові слова: підготовка майбутніх учителів суспільствознавчої галузі, національна ідентичність учнів ліцеїв, методологічні підходи, психологічні механізми формування національної ідентичності, ціннісно-смислове поле національної ідентичності. 
Постановка проблеми. Вивчення проблеми формування національної ідентичності учнів ліцеїв потребує інтеграції різних наукових знань, які б допомогли виявити багатоаспектність досліджуваного феномену та чітко визначали наукові підходи до підготовки майбутніх учителів суспільствознавчої галузі у сучасних умовах з огляду на виклики.

На сьогодні такими викликами $є$ маргінальна або розмита національна ідентичність молоді, високі міграційні настрої і бажання самореалізуватися, відірваність від національної культури, ціннісна невизначеність i зорієнтованість на псевдоцінності, підміна смисложиттєвих цінностей тимчасовими цілями, бажання уникнути служби в армії, громадянська пасивність тощо.

Водночас сучасні проблеми національної ідентичності потрібно розглядати у контексті процесів глобалізованого світу, де кожна національна спільнота вибудовує внутрішню і зовнішню стратегію розвитку на засадах універсалізму, міждержавної взаємодії, поваги до інших етносів і народів. Вироблені засади міжнародного права у діяльності міжнародних інститутів, зокрема ООН, спрямовані на забезпечення фундаментальних цінностей людства, таких як: свободи, гідності, справедливості, толерантності.

Аналіз останніх досліджень 3 проблеми. Формування національної ідентичності $є$ питанням становлення, розвитку та існування держави, що перебувало у полі зору науковців, які намагалися розв'язати його з точки зору суспільних цінностей та запитів.

Філософські підходи до розв'язання проблеми знаходимо у працях О. Білого, Є. Бистрицького, Р. Зимовця, Р. Кобець, С. Лозниці, С. Пролєєва, В. Кременя, В. Ткаченка. У психології національну ідентичність досліджували Д. Абрамс, М. Боришевський, Е. Еріксон, Е. Зеєр, С. Страйкер, Д. Тьорнер. Педагогічні дослідження національної ідентичності представлено працями Р. Сойчук, І. Шкільної.

Мета статті - висвітлити методологічні засади підготовки майбутніх учителів суспільствознавчої галузі до формування національної ідентичності учнів ліцеїв.

Методи дослідження: теоретичні - аналіз, систематизація та узагальнення методологічних засад та наукових принципів з проблеми підготовки майбутніх учителів суспільствознавчої галузі до формування національної ідентичності учнів ліцеїв.

Виклад основного матеріалу дослідження. Українська держава будує таке суспільство, де рівноправними $є$ усі ідентичності, що складають націю, і що гарантується Конституцією та законами України, реалізується через державні структури та широке відображення у публічній сфері, зокрема й у ЗМІ. Враховуючи це, національна ідентичність $\epsilon$ умовою збереження, безпеки і розбудови України.

Водночас усі кризи, що виникають у результаті ідентичних зрушень мають вирішуватися на основі спільних для всіх учасників цінностей, життєвих смислів та моральних засад.

Загрозою національної ідентичності, 3 точки зору О. Білого, Є. Бистрицького, Р. Зимовця, Р. Кобець, С. Лозниці, С. Пролєєва, $є$ так звана «політика невизнання», де інша ідентичність визнається такою, що несе загрозу і їй приписуються найбільш негативні властивості. Політика невизнання «продовжує активно діяти як світогляд, політика, колективні упередження тощо, навіть за умови бажаного інституційного закріплення спільних цінностей глобальної демократії ідентичностей» (Бистрицький, Пролєєв, Білий, Лозниця, Зимовець та Кобець, 2018, с.26).

Наслідком політики невизнання можуть бути військові дії, локальні військові конфлікти, які завдають непоправної шкоди мирному співіснуванню різних країн і націй, залишаючи глибокий слід втрат в історії. 
Негативно позначаються на національній ідентичності особистості упередження та негативні стереотипи, внаслідок яких увесь народ як єдиний суб'єкт наділяється якимись негативними характеристиками, спрощеними карикатурними образами, які можуть підкріплюватися пересудами, як інструментом пропаганди, висловлюваннями відомих людей у зарубіжжі та своїй країні, посилюватися інформаційною війною через 3МI, соцмережі, мистецтво тощо.

Методологічні засади підготовки майбутніх учителів предметів суспільствознавчої галузі до формування національної ідентичності учнів ліцеїв пронизують усю експериментальну роботу і визначають їі результативність.

Реалізація експериментального дослідження, присвяченого підготовці майбутніх учителів предметів суспільствознавчої галузі до формування національної ідентичності учнів ліцеїв, опиралася на особистісно орієнтований, аксіологічний, компетентнісний методологічні підходи.

Особистісно орієнтований підхід є основою сучасного гуманістичного виховання, що протистоїть директивній педагогіці, в центрі якого особистість майбутнього учителя, здатного до саморозвитку, особистісної і професійної самореалізації. Є. Бондаревська розглядає особистісно орієнтований підхід з точки зору його педагогічної керованості у соціальній адаптації, входження в культуру, творчій самореалізації особистості відповідно до її вікових особливостей. Ставлення до вихованців як суб'єктів власного життя спонукає їх до розвитку моральної i національної самосвідомості, творення нових смислів, адекватного самооцінювання, відповідального вибору стратегії поведінки, самоствердження тощо.

Особистісно орієнтований підхід у підготовці майбутніх учителів суспільствознавчої галузі грунтується на врахуванні вікових та індивідуальних особливостей, професійної спрямованості та спеціалізації, диференціації у роботі зі студентами та використання навчальних програм різного рівня складності.

Особистісно орієнтований підхід передбачає розвиток індивідуальних і громадянських якостей, почуття гідності, національної ідентифікації особистості, на основі урахування їі моральних потреб та запитів, що $є$ надзвичайно важливим у формуванні національної ідентичності зростаючої особистості.

Аксіологічний niдxiд у педагогіці розкрили В. Андрущенко, С. Вітвіцька, І. Бех, О. Єфімова, А. Кир'якова, В. Лутай, Н. Ткачова (Андрущенко та Лутай, 2004; Вітвицька, 2015; Ефимова, 2012; Кирьякова, 2012; Ткачова, 2006), і які визначили його роль у підготовці майбутніх учителів. На їхню думку, аксіологічний підхід є визначальним у формуванні фахових компетентностей, де враховуються бажання, мотивація, професійні інтереси, ціннісні орієнтири, які характеризують ціннісно-мотиваційну сферу особистості майбутнього учителя. Отже, процес підготовки майбутнього фахівця суспільствознавчої галузі до формування національної ідентичності учнів ліцеїв має опиратися на моральні цінності, які $\epsilon$ «методологією творчого перетворення світу» (Шукшунов, Взятышев и Романкова, 2011), що забезпечують професійне і особистісне становлення, розвиток особистості та її самореалізацію.

3 огляду на це, аксіологічний підхід забезпечує:

- інтеріоризацію моральних цінностей та формування відповідних якостей;

- свободу вибору та відповідальність за результати діяльності;

- розвиток моральної та духовної сфери особистості майбутнього учителя суспільствознавчої галузі, який орієнтуватиметься у своїй професійній діяльності на вищі цінності; 
- соціальну адаптацію та громадянську активність;

- особистісне і професійне зростання.

Згідно з аксіологічним підходом, майбутній учитель предметів суспільствознавчої галузі виступає суб'єктом національної культури і носієм національних цінностей. Завдання вчителя полягає в тому, щоб національні цінності набули особистісної значущості для вихованців, тобто стали такими, що визначають характер їхньої поведінки і морального вибору.

У цьому контексті особлива увага звертається на випереджальний характер вищої освіти, «що передує еволюції суспільства» (Селезнева, 2004, с. 35-44). На тлі реформ вищої освіти дедалі більшої ваги набуває виховання особистості на основі цінностей. А тому підготовка майбутніх учителів предметів суспільствознавчої галузі має бути не вузькопрофільною, а готувати студентів до життя в умовах глобалізаційних впливів, швидкоплинних змін, з добре сформованим критичним і креативним мисленням, здатних проявляти активну громадянську позицію та приймати відповідальні рішення у різних життєвих ситуаціях.

Аксіологічний підхід у підготовці майбутніх учителів до формування національної ідентичності учнів ліцеїв передбачає формування моральних цінностей та ідеалів, усвідомлення своєї місії та призначення у житті, готовності до самоудосконалення.

Компетентнісний підхід спрямований на досягнення інтегральних показників у підготовці майбутніх учителів предметів суспільствознавчої галузі, що реалізується через формування загальних та професійних компетентностей. У ході навчання студентів у закладі вищої освіти ключові компетентності розвиваються, оновлюються та збагачуються новим досвідом, здатностями. На думку І. Беха, зазначений підхід «репрезентується сформованістю у суб'єкта наукового поняття «компетентність» як єдності, де науково орієнтована основа дії визначає логіку іiі практичного використання» (Бех, 2012, с.30). Компетентнісний підхід забезпечує професіоналізацію та соціалізацію студентської молоді, що $\epsilon$ важливою умовою формування національної ідентичності учнів ліцеїв. Компетентнісний підхід протистоїть репродуктивному підходу у засвоєнні та відтворенні знань та орієнтує особистість на майбутню професійну діяльність у формуванні національної компетентності.

На наш погляд, слушною є характеристика педагогічних принципів С. Гончаренка, згідно якої вони розглядаються як «інструментальне, дане в категоріях діяльності вираження педагогічної концепції, це методичне вираження пізнаних законів i закономірностей, це знання про цілі, суть, зміст, структуру навчання, виражене у формі, яка дає можливість використати їх як регулятивні норми практики» (Гончаренко, 2012, с.101).

Найважливішими принципами підготовки майбутніх учителів предметів суспільствознавчої галузі до формування національної ідентичності учнів ліцеїв $є$ :

- приниип моделювання професійної діяльності у навчально-виховному процесі закладу вищої освіти полягає у виявленні завдань з формування національної ідентичності учнів ліцеїв та трансформацію їх у завдання підготовки майбутніх вчителів суспільствознавчої галузі, що обумовлює вибір доцільних форм, методів і засобів навчання та виховання;

принйи інтегративності дозволяє не лише залучати різних суб'єктів до навчально-виховного процесу закладу вищої освіти, а й також створювати інтегровані програми і курси для майбутніх вчителів суспільствознавчої галузі; 
- принции єдності соціалізащіï $i$ професіоналізації характеризує педагогічно керований процес розвитку і становлення особистості відповідно до обраної професійної діяльності та іiї соціальної значущості;

- $\quad$ приничи професійної мобільності забезпечує швидке реагування на виклики у сфері формування національної ідентичності, опанування нових технологій, методик, засобів з метою оптимізації виховного процесу ліцею;

- $\quad$ принции гуманізму полягає у визнанні людини найвищою цінністю, пріоритетності iï прав, інтересів та створення умов для самореалізації;

- принциип природовідповідності грунтується на врахуванні педагогічних та психологічних закономірностей, вікових та індивідуальних особливостей;

принции ментальності визначає розуміння етнопсихологічних особливостей вихованців, національної специфіки та характеру процесу виховання дітей, нейтралізації стереотипів;

- $\quad$ принции суб 'єкm-суб 'єктної взаємодії, з огляду на який береться до уваги позиція вихованця і який виступає не об'єктом, а суб'єктом виховного процесу.

Ціннісно-смислове поле національної ідентичності характеризують національна мова, національна ідея, національні інтереси, національна згода, національна культура, історія та традиції нації.

Мова є одним з провідних чинників національної ідентичності, що вирізняє націю, народ 3-поміж інших. Втрата мови призводить до втрати ідентичності та набуття іншої ідентичності.

Національна ідея відображає прагнення та національний характер, об’єднує різні покоління з метою прогресивного розвитку і реалізації місії України у світі. Чітко визначена національна ідея є свого роду стратегією національного самоствердження, що опирається на загальну підтримку і здатна консолідувати суспільство у реалізації національних перспектив. Національна ідея має об’єднувати усі етноси і народи, які складають українську націю і бути їм зрозумілою.

Національні інтереси згуртовують усі етноси, що входять до поліетнічної нації як суб'єкта міжнародної діяльності, довкола спільної мети, задач, устремлінь, бажання самоствердитися, посісти гідне місце серед інших народів. Водночас національні інтереси спрямовані на збереження i розвиток держави, людського капіталу, зростання рівня національної свідомості і самосвідомості.

Національна згода є певною домовленістю більшості громадян стосовно самовизначення (конкретна назва нації, державні символи, спільні святині для всіх), національної ідентичності, територіальних кордонів та політичного устрою. Національну згоду можна розглядати як делегування повноважень владі, яка має відповідати очікуванням нації і відстоювати іiі право на суверенність. Національна згода пов'язана 3 процесами ідентифікації спільноти як нації, визначення спільних пріоритетів, завдань, коли другорядні цілі підпорядковуються головним.

Національна культура є середовищем, у якому формується молодь на грунті найкращих зразків, вищих смислів, духовної і матеріальної спадщини та реалізовуються контакти й обмін культурними здобутками з іншими народами.

Iсторія включає національну пам'ять і на засадах історичної правди відображає основні віхи розвитку й життєдіяльності нації, її становлення, найважливіші досягнення, боротьбу за самозбереження, драматичні сторінки народу.

Традищіï, відтворюючи певні культурні зразки відмінні від інших народів, відображають універсалії буття нації, є втіленням спільного досвіду для всіх. 
Психологічними механізмами формування національної ідентичності особистості виступають: національна свідомість i самосвідомість, національне самопізнання, національне самоствердження.

Національна свідомість $і$ самосвідомість виступають психологічними механізмами формування національної ідентичності й відіграють консолідуючу роль, об'єднуючи різні етноси, що проживають на території однієї країни.

На складність цих процесів звертають увагу філософи і психологи (Кон, 1984, с.29), відмінності у проявах національної свідомості й самосвідомості різних соціальних груп (Каширіна, 1999, с.29), автономність феноменів свідомості і самосвідомості (Чеснокова, 1987, с.63), зв'язок з мовою (Спиркин, 1972, с.83).

Національна свідомість і самосвідомість $€$ взаємопов'язаними, де проявами національної (колективної) свідомості є знання нації про себе, національні цінності, національну ідею, національні ідеали, місію, тоді як національної (індивідуальної) самосвідомості усвідомлення особливостей і відмінностей від інших націй та перспектив розвитку, усвідомлення власної причетності і приналежності до української нації.

Національна свідомість формується упродовж усієї історії існування нації на різних рівнях: побутовому (традиції, норми, правила, етикет, стереотипи); духовному (вірування, ідеї, ідеали, зразки); державному (права, свободи, обов'язки).

Національна самосвідомість виявляється у національній ідентифікації. Так, у тлумаченні М. Боришевського вона виступає усвідомленням «особистістю себе часткою певної національної (етнічної) спільноти та оцінку себе як носія національних (етнічних) цінностей, що склалися в процесі тривалого історичного розвитку національної спільноти, іiї самореалізації як суб’єкта соціальної дійсності» (Боришевський, 2000, с.63).

Національне самопізнання ставить за мету усвідомлення специфічних національних рис, характеру, свого «Я» - національного через звернення до історичної пам'яті та засвоєння уроків історії. Національне самопізнання як механізм утвердження українськості та іiі відродження розглядав М. Грушевський, вважаючи (збережено правопис та стиль): «Справді невеселий переважно образ дає нам наша історія, сумніший може часом ніж нинішні, але суспільність, що має віру в себе, мусить мати і відвагу глянути на неприкрашену правду свого минулого, щоб зачерпнути в ній не зневіру, а силу. «Увъсте истину, и истина свободить вы!» - сю девізу діячів нашого національного відродження можемо повторити й по пятьдесятьох літах, додавши тільки «волю» і «працю», як неминучих спутників знання в поході до забезпечення ліпшої будучности свому народу» (Грушевський, 1991, с. LXXXII). На переконання М. Грушевського, національне самопізнання має опиратися на національну освіту, мову, історію, етнологію та екологічну культуру.

Також національне самопізнання передбачає і ставлення до себе як представника нації, продовжувача певних традицій, соціальну взаємодію та комунікації. Ставлення до себе як представника нації впливає на самооцінку, яка може бути адекватною чи неадекватною.

Національне самоствердження є психологічним механізмом реалізації національної ідентичності особистості як позитивної за своїм характером, на основі мобілізації (етнонаціональної, політичної) та згуртування заради забезпечення національних інтересів чи досягнення значущих цілей. Найкраще національне самоствердження проявляється у втіленні національної ідеї. «Розглядаючи перспективи виховання національного самоствердження учнівської молоді в Україні, варто спрямовувати цей процес на формування громадянської нації, де кожен член української спільноти повинен усвідомлювати власну причетність до утвердження української нації, громадянського 
суспільства, відповідати перед своєю національною державою й солідарно співпрацювати 3 іншими громадянами на користь громади, держави, нації» (Сойчук, 2016, с.23). Національне самоствердження пов'язане також з відданістю Батьківщині, солідарністю у відстоюванні іiі інтересів, утвердженні позитивного іміджу України, готовністю добровільно служити громаді/суспільству, робити власний внесок на користь спільноти, конструктивно взаємодіяти з іншими, самоудосконалюватися.

Підготовка майбутніх учителів предметів суспільствознавчої галузі до формування національної ідентичності учнів ліцеїв в сучасних умовах має здійснюватися на основі Концепції національно-патріотичного виховання в системі освіти України та Стратегії національно-патріотичного виховання дітей та молоді на 2020-2025 рр., які передбачають активну взаємодію освітніх закладів, органів влади, місцевого самоврядування, ресурсних центрів. Їх особливістю $є$ створення умов для реалізації «діяльнісного патріотизму», де серед завдань $€$ формування національної ідентичності, розуміння історії і самобутності українського народу.

У «Програмі українського патріотичного виховання дітей та учнівської молоді» I. Беха, К. Чорної наголошується на єдності українського народу у його прагненні до миру, злагоди та вирішенні низки проблем. Зокрема, таких як меншовартісність, зневіра у цивілізоване життя в Україні, відсутність етно-національної консолідації, сепаратизм в окремих регіонах. Автори вважають, що виховання патріота-громадянина має здійснюватися в умовах полікультурності, на основі «взаємозв'язку етнокультур української політичної нації у минулому і майбутньому, спільної для всіх етносів долі та мети» (Бех та Чорна, 2014, с.10). Завданням Програми є виховання гідних громадян, готових розбудовувати і захищати Україну, здатних конструктивно взаємодіяти, цивілізовано відстоювати свої права i вирішувати конфліктні ситуації.

Особливістю Програми «Нова українська школа» у поступі до цінностей» $є$ іiї практична цінність та добре розуміння сучасних викликів у вихованні дітей та молоді. Авторам вдалося окреслити внутрішні і зовнішні виклики. Серед зовнішніх викликів: ідеологічний, ціннісної убезпеченості, релігійний, історичної упередженості, маніпулювання свідомістю, екологічний, естетико-ціннісної спрямованості, інформаційного впливу, цінності здоров'язбереження молоді. Проте внутрішнім викликом для безпеки нації визначено національну ідентифікацію, «яка втілюється у почуттях-цінностях - «Я - Українець» - «ми -Українці» (Бех, Алєксєєнко, Журба, Кириленко, Корецька, Остапенко,.... та Шкільна, 2019 , с.4), що полягає у причетності до роду, нації. У програмі пропонуються традиційні та інноваційні форми і методи виховання моральних, патріотичних якостей та національної ідентичності особистості.

Висновки і перспективи подальших розвідок. Отже, розглянуті методологічні підходи розроблення проблеми підготовки майбутніх учителів предметів суспільствознавчої галузі до формування національної ідентичності учнів ліцеїв засвідчують про взаємозв'язок та взаємозалежність наукових підходів та принципів, що дає змогу визначити концептуальні засади та ціннісно-смислове поле дослідження.

Дослідження не вичерпало усіх аспектів підготовки майбутніх учителів суспільствознавчої галузі до формування національної ідентичності в учнів ліцею. Подальшого вивчення потребує діагностика стану підготовки майбутніх учителів суспільствознавчої галузі до формування національної ідентичності в учнів ліцеїв та виявлення рівнів підготовленості, а також вивчення основних проблем та тенденцій у цій царині. 


\section{СПИСОК ВИКОРИСТАНИХ ДЖЕРЕЛ}

Бистрицький, Є., Пролєєв, С., Білий, О., Лозниця, С., Зимовець та Кобець, Р. (2018). Національна ідентичність і громадянське суспільство. Київ: Дух і літера. 452 с.

Андрущенко, В. та Лутай, В. (2004). Філософія освіти в Україні: стан проблеми та перспективи розвитку. Наукові записки АНВШ Украӥни. (Вип. 6), с.59-71.

Вітвицька, С. (2015). Аксіологічний підхід до виховання особистості майбутнього вчителя. Креативна педагогіка: науково-методичний журнал. (Вип. 10), с.63-67.

Ефимова, Е. (2012). Аксиологический подход как методологическая основа формирования социальной устойчивости профессионала. Российский научный журнал, 1(26), c.177-183.

Кирьякова, А. (2012). Ценностные ориентиры университетского образования. Вестник ОГУ, 2 (121), c.27-33.

Ткачова, Н. (2006). Аксіологічний підхід до організації педагогічного процесу в загальноосвітньому навчальному закладі. Луганськ: ЛНПУ імені Т. Г. Шевченка, 300 с.

Шукшунов С. Взятышев, В.Ф. и Романкова Л. И. (2011). Инновационное образование: идеи, приниипы, модели. Москва: МАНВШ, 300 с.

Селезнева, Н. (2004). Размышление о качестве образования: международный аспект. Высшее образование сегодня, № 4, с. 35- 44.

Бех, І. (2012). Особистість у просторі духовного розвитку. Навчальний посібник. Київ: Академвидав, $256 \mathrm{c}$.

Гончаренко, С.(2012). Педагогічні закони, закономірності, приниипи. Сучасне тлумачення. Рівне: Волинські обереги, 192 с.

Каширина, В. (1999). Соииальное самосознание человечества и перспективы его развития. Доктор философских наук. Ставропольский государственный университет.

Кон, И. (1984). В поисках себя. Москва: Политиздат, 335 с.

Спиркин, А. (1972). Сознание и самосознание. Москва: Политиздат, 303 с.

Чеснокова, И. (1987). Проблемы самосознания и психологии. Москва: Наука, 288 с.

Боришевський, М. (2000). Національна самосвідомість у громадянському становленні особистості. Київ: Беркут, 76 с.

Грушевський, М. (1991). Історія України - Руси: в 11 т. Київ: Наукова думка, Т.1., 648 с.

Сойчук, Р. (2016). Виховання начіонального самоствердження учнівської молоді. Рівне: О.Зень, 416 с.

Бех, І.та Чорна, К. (2014). Програма украӥнського патріотичного виховання дітей та учнівської молоді. Київ: ІПВ НАПНУ,48 с.

Бех, І, Алєксєєнко, Т., Журба, К., Кириленко, С., Корецька, Л., Остапенко, О. та Шкільна, І. (2019). Програма «Нова украӥнська школа» у поступі до иінностей. Київ: ІПВ НАПНУ, 43 c.

\section{REFERENCES}

Bystrytskyi, Ye., Prolieiev, S., Bilyi, O., Loznytsia, S., Zymovets ta Kobets, R. ( 2018). Natsionalna identychnist i hromadianske suspilstvo [National Identity and Civil Society]. Kyiv: Dukh i litera. 452 s. (in Ukrainian)

Andrushchenko, V. ta Lutai, V. (2004). Filosofiia osvity $v$ Ukraini: stan problemy ta perspektyvy rozvytku [The philosophy of Education in Ukraine: the State of the Problem and Prospects for Development]. Naukovi zapysky ANVSh Ukrainy. (Vyp. 6), s.59-71. (in Ukrainian) 
Vitvytska, S. (2015). Aksiolohichnyi pidkhid do vykhovannia osobystosti maibutnoho vchytelia [Axiological Approach to the Education of the Future Teacher's Personality]. Kreatyvna pedahohika: naukovo-metodychnyi zhurnal. (Vyp. 10), s.63-67. (in Ukrainian)

Efimova, E. (2012). Aksiologicheskii podkhod kak metodologicheskaya osnova formirovaniya sotsialnoi ustoichivosti professionala [Axiological Approach as a Methodological basis for the Formation of Social Sustainability of a Professional]. Rossiiskii nauchnyi zhurnal, No1(26), s.177183. (in Ukrainian)

Kiryakova, A. (2012). Tsennostnye orientiry universitetskogo obrazovaniya [Values of University Education]. Vestnik OGU, 2 (121), s.27-33. (in Ukrainian)

Tkachova, N. (2006). Aksiolohichnyi pidkhid do orhanizatsii pedahohichnoho protsesu $v$ zahalnoosvitnomu navchalnomu zakladi [Axiological Approach to the Organization of the Pedagogical Process in a Comprehensive Educational Institution]. Luhansk: LNPU imeni T.H. Shevchenka, 300 s. (in Ukrainian)

Shukshunov S. , Vzyatyshev, V. ta Romankova L. (2011). Innovatsionnoe obrazovanie: idei, printsipy, modeli [Innovative Education: Ideas, Principles, Models]. Moskva: MANVSh, 300 s. (in Ukrainian)

Selezneva, N. (2004). Razmyshlenie o kachestve obrazovaniya: mezhdunarodnyi aspekt [Thinking about the Quality of Education: an International Dimension]. Vysshee obrazovanie segodnya, No 4, s. 35-44. (in Russian)

Bekh, I. (2012). Osobystist u prostori dukhovnoho rozvytku [Personality in the Space of Spiritual Development]. Navchalnyi posibnyk. Kyiv: Akademvydav, 256 s. (in Ukrainian)

Honcharenko, S. (2012). Pedahohichni zakony, zakonomirnosti, pryntsypy [Pedagogical Laws, Consistent Pattern, Principles]. Suchasne tlumachennia. Rivne: Volynski oberehy, 192 s. (in Ukrainian)

Kashirina, V. (1999). Sotsialnoe samosoznanie chelovechestva i perspektivy ego razvitiya [Social Self-awareness of Mankind and Prospects for its Development]. Doktor filosofskikh nauk. Stavropolskii gosudarstvennyi universitet. (in Russian)

Kon, I. (1984). V poiskakh sebya [Searching Yourself]. Moskva: Politizdat, 335 s. (in Russian)

Spirkin, A. (1972). Soznanie i samosoznanie [Consciousness and Self-awareness]. Moskva: Politizdat, 303 s. (in Russian)

Chesnokova, I. (1987). Problemy samosoznaniya i psikhologii [Problems of Consciousness and Psychology]. Moskva: Nauka, 288 s. (in Russian)

Boryshevskyi, M. (2000). Natsionalna samosvidomist u hromadianskomu stanovlenni osobystosti [National Consciousness in the Civil Formation of the Individual]. Kyiv: Berkut, $76 \mathrm{~s}$. (in Ukrainian)

Hrushevskyi, M. (1991). Istoriia Ukrainy - Rusy: v 11 t. [History of Ukraine - Rus: in 11 volumes]. Kyiv: Naukova dumka, T.1., 648 s. (in Ukrainian)

Soichuk, R.(2016). Vykhovannia natsionalnoho samostverdzhennia uchnivskoi molodi [Shaping of National Self-affirmation of Student Youth]. Rivne: O.Zen, 416 s. (in Ukrainian)

Bekh, I.ta Chorna, K. (2014). Prohrama ukrainskoho patriotychnoho vykhovannia ditei ta uchnivskoi molodi [Program of Ukrainian Patriotic Education of Children and Student Youth]. Kyiv: IPV NAPNU,48 s. (in Ukrainian)

Bekh, I, Alieksieienko, T, Zhurba, K., Kyrylenko, S., Koretska, L., Ostapenko, O. ta Shkilna, I. (2019). Prohrama «Nova ukrainska shkola» u postupi do tsinnostei [The New Ukrainian School Program in the Process of Moving towards Values]. Kyiv: IPV NAPNU, 43 s. (in Ukrainian) 


\title{
METHODOLOGICAL PRINCIPLES OF TRAINING OF FUTURE SOCIAL SCIENCES TEACHERS TO FORMATION OF NATIONAL IDENTITY OF STUDENTS OF LYCEUM
}

\author{
Nelia Onyshchenko \\ Postgraduate Student at the Department \\ of Teaching Methods of \\ Social Disciplines and Gender Education, \\ M.P. Drahomanov National Pedagogical University, \\ Kyiv, Ukraine \\ ORCID: 0000-0002-6135-6196 \\ e-mail: nelionyshchenko@gmail.com
}

\begin{abstract}
The article deals with the methodological principles of training future teachers of social science subjects for formation of national identity for students of lyceums. Challenges (marginal or blurred national identity of youth, high migration attitudes and desire to selfrealization, isolation from national culture, value ambiguity and orientation to pseudo-values, substitution of meaningful life values for temporary goals, desire to avoid serving in the army, civic passivity) and problems concerning the training of future teachers of social science to the formation of national identity of personality are investigated.

The obstacles to the formation of national identity in youth are the politics of non-recognition, negative stereotypes, prejudices, information war. The following methods are used in the work: theoretical - analysis, systematization and generalization of methodological foundations and scientific principles on the problem of training of future teachers of social sciences in formation of national identity of students of lyceums. The main methodological approaches (personally oriented, axiological, competent) and principles (modeling of professional activity in the educational process of higher education institution, integrativity, unity of socialization and professionalization, professional mobility, nature, humanism, mentality) are revealed in the article. The article outlines the value-meaning field of national identity in the context of national language, national idea, national interests, national consensus, national culture, history and traditions of the nation, as well as psychological mechanisms of formation of national identity (national consciousness and selfconsciousness, national self-awareness). The normative base on the study problem was analyzed. All the methodological approaches discussed regarding the problem of training future teachers of social science subjects to form the national identity for lyceum students testify to the interconnectedness and interdependence of scientific approaches and principles.

Keywords: future teachers of social sciences training, national identity of students of lyceums, methodological approaches, psychological mechanisms of formation of national identity, valuesemantic field of national identity
\end{abstract}

Стаття надійшла до редакиії 06. 03. 2020 р. 